\title{
Mechanical Properties of Foamed Concrete with the Addition of Oil Palm Trunk Fibre
}

\section{Md Azree Othuman Mydin}

To Link this Article: http://dx.doi.org/10.6007/IJARBSS/v12-i1/11926

DOI:10.6007/IJARBSS/v12-i1/11926

Received: 12 November 2021, Revised: 15 December 2021, Accepted: 28 December 2021

Published Online: 11 January 2022

In-Text Citation: (Mydin, 2022)

To Cite this Article: Mydin, M. A. O. (2022). Mechanical Properties of Foamed Concrete with the Addition of Oil Palm Trunk Fibre. International Journal of Academic Research in Business and Social Sciences, 12(1), 253264.

Copyright: (c) 2022 The Author(s)

Published by Human Resource Management Academic Research Society (www.hrmars.com)

This article is published under the Creative Commons Attribution (CC BY 4.0) license. Anyone may reproduce, distribute, translate and create derivative works of this article (for both commercial and non0-commercial purposes), subject to full attribution to the original publication and authors. The full terms of this license may be seen at: http://creativecommons.org/licences/by/4.0/legalcode

Vol. 12, No. 1, 2022, Pg. $253-264$

Full Terms \& Conditions of access and use can be found at http://hrmars.com/index.php/pages/detail/publication-ethics 


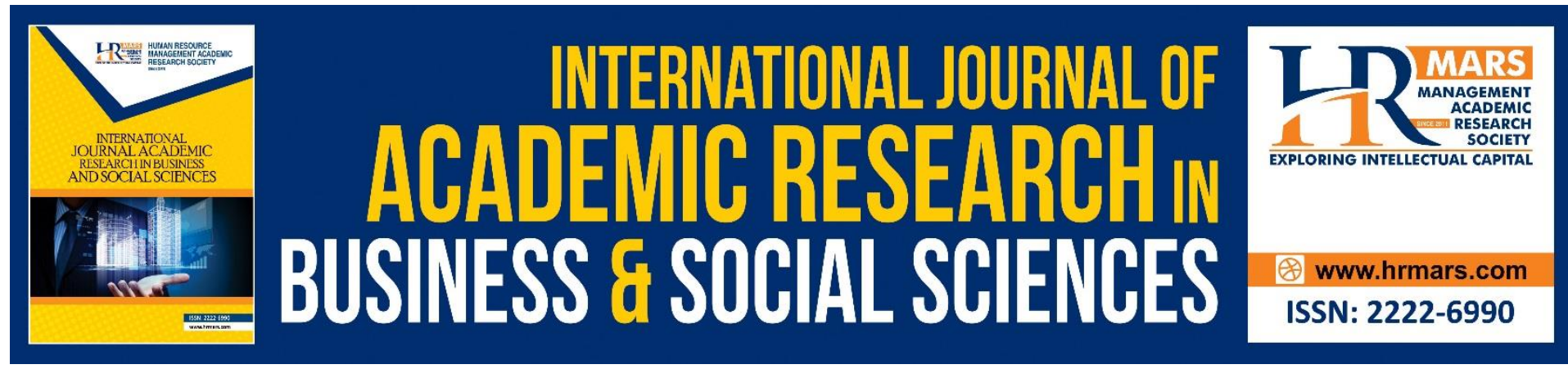

\title{
Mechanical Properties of Foamed Concrete with the Addition of Oil Palm Trunk Fibre
}

\author{
Md Azree Othuman Mydin \\ School of Housing, Building and Planning, Universiti Sains Malaysia, 11800, Penang, \\ MALAYSIA \\ Email: azree@usm.my
}

\begin{abstract}
Nowadays, in Malaysia, one of the country's challenges is the improper management and disposal of solid waste. The leading sector that generates most of the solid waste in Malaysia is the agricultural sector from oil palm fibre, similar to oil palm trunk fibre, which is also be used as an additive in producing foamed concrete (FC). However, FC presents a weakness in tension, which can be reduced by adding an adequate volume of waste biomass by-product such as oil palm trunk (OPT) fibre. Accordingly, this study was undertaken to investigate the potential of utilising OPT fibre as a reinforcement in FC. There were four different volume fractions of OPT fibre: $0.15 \%, 0.30 \%, 0.45 \%$, and $0.60 \%$ used as an additive to the FC mix. Two densities, $600 \mathrm{~kg} / \mathrm{m}^{3}$ and $1200 \mathrm{~kg} / \mathrm{m}^{3}$, were cast and tested. All FC specimens were then prepared and left to cure and exposed to the elements for 7, 28, and 56 days. In this study, mechanical properties were examined. The results showed that the addition of OPT fibre in FC improved the compressive strength, flexural strength, tensile strength of the FC. OPT's surface roughness was proved beneficial for fibre to matrix interfacial bonding since a coarser surface permit OPT fibre and matrix interlocking in the hardened cement matrix. Based on the results of this study for $600 \mathrm{~kg} / \mathrm{m}^{3}$ density, $0.30 \%$ volume fraction was the optimum amount added to the FC to achieve the best durability and mechanical properties. While for $1200 \mathrm{~kg} / \mathrm{m}^{3}, 0.45 \%$ volume fraction of OPT was the optimum percentage.
\end{abstract}

Keywords: Foamed Concrete, Compressive Strength, Flexural, Tensile, Tensile Properties

\section{Introduction}

Foamed concrete (FC) as a material in the construction industry is not new since it was initially patented in 1923 though on a limited scale (Moon et al., 2015). It was only until the late 1970s that the material started to be used in the Netherlands for ground engineering applications and voids filling works (Müllera et.al., 2014). In 1987 a full-scale assessment on the application of lightweight foam concrete (LFC) as a trench reinstatement was conducted in the United Kingdom (UK), and the achievement of this trial led to the extensive application of FC for trench reinstatement, in which other applications soon followed (Lim et al., 2014). Since then, FC as a building material has become more prominent and widespread in expanding the production and range of applications (Jalal et al., 2017). Over the last 20 years, FC has primarily been used for bulk filling, trench reinstatements, backfill to retaining walls 
and bridge abutments, insulation to foundations and roof tiles, sound insulation, stabilising soils (especially in the construction of embankment slopes), grouting for tunnel works, sandwich filling for precast units and pipeline infill (Mohammad Hosseini et. al, 2016). However, there has been a growing interest in using FC as a lightweight non-structural and semi-structural material in building construction (Sari and Sani, 2017) to take advantage of its lightweight and good insulation properties during the last few years (Thakrele, 2014).

However, FC is known to be a reasonably brittle material when exposed to normal stresses and impact loads, where its tensile strength is about one-tenth of its compressive strength (Ramamurthy et al., 2009). As a result, FC flexural members could not support such loads that usually occur during their service life for these characteristics (Mahzabin et al., 2018). In the past, FC members reinforced with continuous reinforcing bars were used to withstand tensile stresses and compensate for the lack of ductility and strength (Kim et al., 2010). Furthermore, steel reinforcement was utilised to overcome high potentially tensile stresses and shear stresses at a critical location in FC members (Tangchirapat and Jaturapitakkul, 2016). Even though the addition of steel reinforcement increases the strength of FC, the development of micro-cracks needs to be controlled to fabricate the concrete with homogenous tensile properties (Suhendro, 2014).

Therefore, fibre is seen as a solution to develop FC with enhanced flexural and tensile strength, which is a new form of binder that can combine Portland cement in bonding with cement matrices. The fibres are mostly discontinuous, randomly distributed throughout the cement matrices (Elrahman et al., 2019). The inclusion of fibres in FC is to delay and control the tensile cracking of composite material (Munir et al., 2015). Fibres thus transform the inherent unstable tensile crack propagation to slow controlled crack growth. This crack controlling properties of the fibre helped to reinforce the delays and the initiation of flexural and shear cracking (Memon et al., 2018). It imparts extensive post cracking behaviour and extensively enhances the ductility of the composite (Jhatial et al., 2017). Fibres, which are randomly $t$ random dispersed throughout the $\mathrm{FC}$, could overcome cracks and control shrinkage more efficiently (Hamad, 2014). These materials have exceptional combinations of strength and energy absorption capacity. In general, fibre reinforcement is not a substitution for conventional steel reinforcement since the fibres and steel reinforcement have their own role in FC technology (Othuman Mydin et al., 2016), and there are many applications to which both fibres and continuous reinforcing steel bars can be used together (Muthusamy and Zamri, 2016). However, fibres are not efficient in withstanding the tensile stresses compared to conventional steel reinforcement (Serri et al., 2014). Fibres are more closely spaced than steel reinforcements, which are better in controlling cracks and shrinkage. As a result, conventional steel reinforcements are used to amplify the load-bearing capacity of the FC member since fibres are more effective in crack control (Kamaruddin et al., 2018).

In Malaysia, the growth in oil palm plantations has produced significant waste products during the replanting process, especially oil palm frond and oil palm trunk (OPT). Nowadays, oil palm fibre waste contributes to about $70 \%$ of the overall total waste in Malaysia (Momeen et al., 2016). Given that oil palm fibre is good in tension and low in density, scientists and engineers worldwide have actively been researching the potential use of this fibre on concrete structure material. The oil palm fibre added to concrete can also be applied to lightweight concretes in determining the optimum composition of this concrete. Hence this research explores the potential utilisation of OPT fibre in FC. 


\section{Material Constituents, Mix Proportion and Tests}

\section{Ordinary Portland Cement}

Ordinary Portland cement (OPC) was used in this study, complying with the BS 12 (BS12, 1996) standard. This product is available in $50 \mathrm{~kg}$ bags and in bulk. Fine inorganic material forms a paste once water is added to the mixture.

\section{Fine Sand}

The fine aggregate used in this study was natural fine sand supplied by a local distributor. Sieve analysis was conducted to assess the suitability of the sand to use according to BS882 (BS882, 1992) and the result is shown in Fig. 1. Fine sand was used with a size of $1.18 \mathrm{~mm}$ to improve the FC flow characteristics and stability.

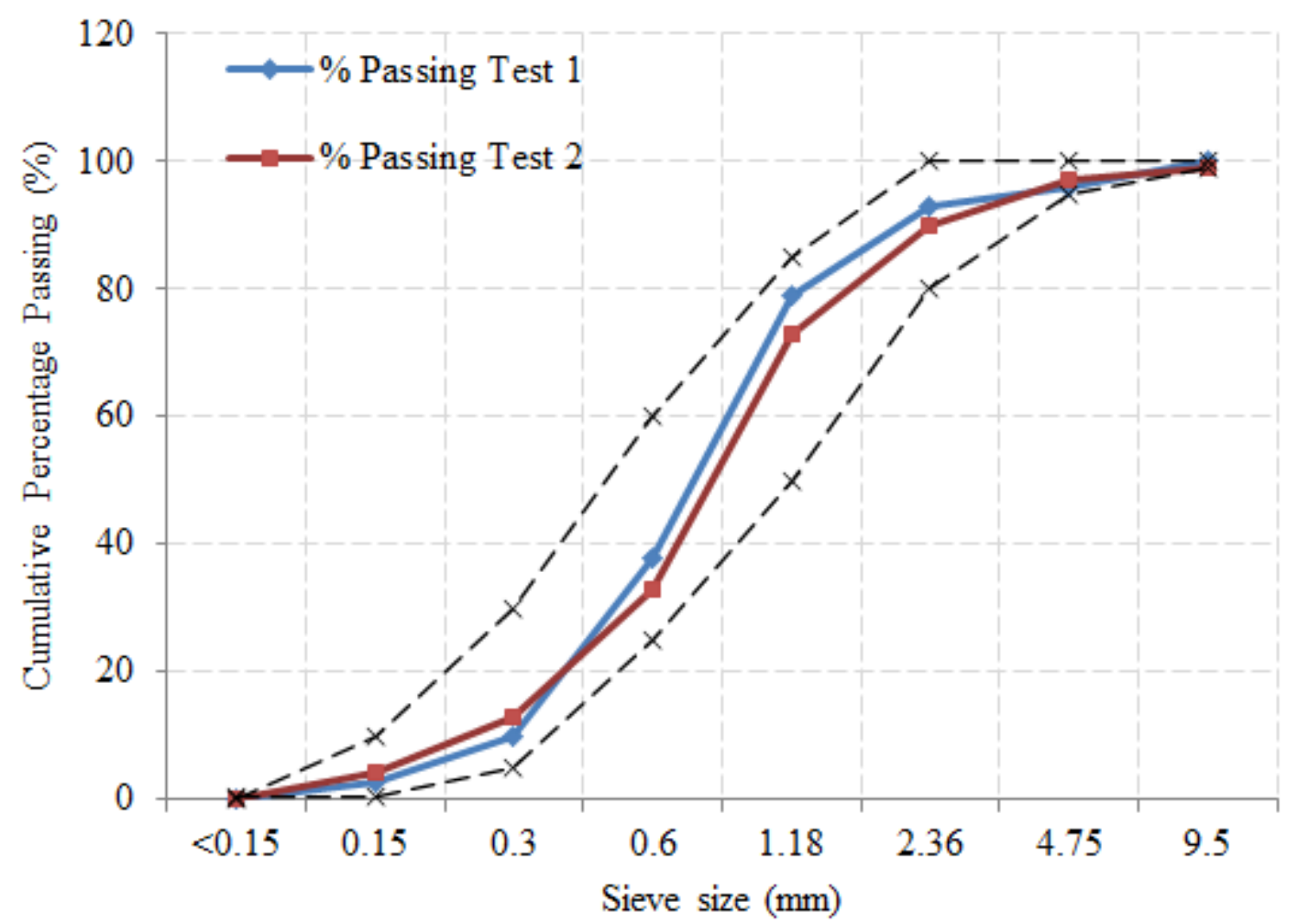

Fig. 1 - Sieve analysis result of fine sand

\section{Stable Foam}

The foam was produced from a generator using foam agents, in which the bubbles were relatively small in size. The protein agent used for this study was Noraite-PA-1, at a ratio of $1: 33$ to the volume of water. The clean water used in the mix together with the protein agent was to create a good foaming agent. The density of FC was determined by the volume of foam added into the mix. The stability of foam is important in producing FC since the generator will act as a medium to transfer the agent into the stable foam. The weight of the foam used in this investigation varied between $60-80 \mathrm{~g} /$ litre.

\section{Oil Palm Trunk Fibre}

This oil palm trunk (OPT) fibre was cleaned five times with clean tap water to remove any debris. The fibre was then dried for 2 days (see Fig. 2). The volume fraction of the fibre used was $0.15 \%, 0.30 \%, 0.45 \%, 0.60 \%$ and $0 \%$ of the total weight mix volume. Table 1 and Table 2 
show the chemical composition and physical properties of OPT fibre used in this study respectively.

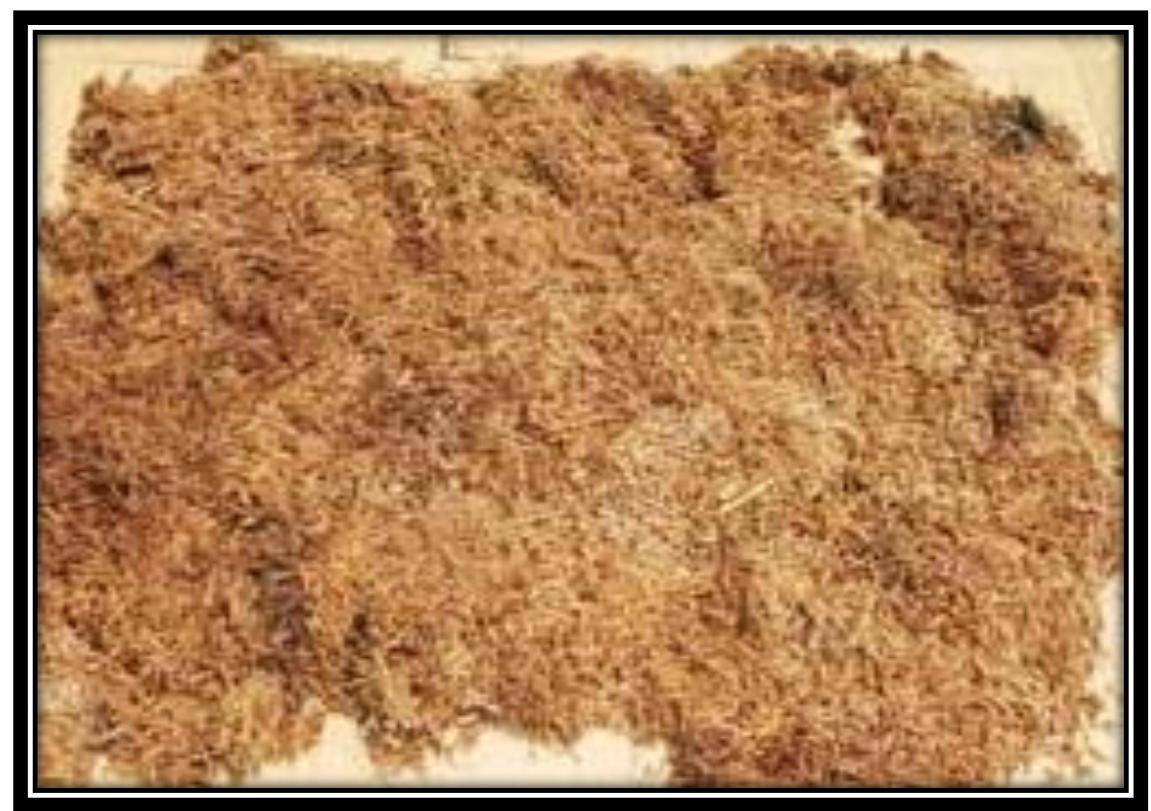

Fig. 2 - Oil palm trunk fibre was dried for two days

Table 1 - Chemical composition of OPT

\begin{tabular}{|c|c|}
\hline Composition & \%, dry weight \\
\hline Cellulose & 31 \\
\hline Hemicellulose & 15 \\
\hline Holocellulose & 42 \\
\hline Lignin & 21 \\
\hline Xylose & 15 \\
\hline Glucose & 30 \\
\hline Ash & 2 \\
\hline
\end{tabular}

Table 2 - Physical properties of OPT

\begin{tabular}{|c|c|}
\hline Component & Properties \\
\hline Fibre length & $15 \mathrm{~mm}$ \\
\hline Fibre diameter & $148 \mathrm{um}$ \\
\hline Lumen width & $17.45 \mathrm{um}$ \\
\hline Density & $0.82 \mathrm{~g} / \mathrm{cm}^{3}$ \\
\hline Runkel ratio & 0.275 \\
\hline Fibril angle (ㅇ) & 42 \\
\hline
\end{tabular}

Mix Design

A total of 10 mixes were prepared for this research. The mix design proportion for $600 \mathrm{~kg} / \mathrm{m}^{3}$ and $1200 \mathrm{~kg} / \mathrm{m}^{3}$ is shown in Table 3. The different per cent of OPT used was $0.15 \%, 0.30 \%$, $0.45 \%, 0.60 \%$ and $0 \%$. For all mixes, the sand-cement ratio was fixed at $1: 1.5$, and the watercement ratio was 0.45 . 
Table 3 - Mix design

\begin{tabular}{|c|c|c|c|c|c|}
\hline Sample & $\begin{array}{c}\text { Mix Density } \\
\left(\mathbf{k g} / \mathbf{m}^{\mathbf{3}} \mathbf{)}\right.\end{array}$ & $\begin{array}{c}\text { Mix Ratio } \\
(\mathbf{S : C : W )}\end{array}$ & $\begin{array}{c}\text { Cement } \\
\mathbf{( k g})\end{array}$ & $\begin{array}{c}\text { Fine sand } \\
\mathbf{( k g )}\end{array}$ & Water (kg) \\
\hline Control mix-600 & 600 & $1: 1.5: 0.45$ & 14.11 & 21.17 & 6.35 \\
\hline $0.15 \%$ OPF-600 & 600 & $1: 1.5: 0.45$ & 14.11 & 21.17 & 6.35 \\
\hline $0.30 \%$ OPF-600 & 600 & $1: 1.5: 0.45$ & 14.11 & 21.17 & 6.35 \\
\hline $0.45 \%$ OPF-600 & 600 & $1: 1.5: 0.45$ & 14.11 & 21.17 & 6.35 \\
\hline $0.60 \%$ OPF-600 & 600 & $1: 1.5: 0.45$ & 14.11 & 21.17 & 6.35 \\
\hline Control mix-1200 & 1200 & $1: 1.5: 0.45$ & 27.40 & 41.09 & 12.33 \\
\hline $0.15 \%$ OPF-1200 & 1200 & $1: 1.5: 0.45$ & 27.40 & 41.09 & 12.33 \\
\hline $0.30 \%$ OPF-1200 & 1200 & $1: 1.5: 0.45$ & 27.40 & 41.09 & 12.33 \\
\hline $0.45 \%$ OPF-1200 & 1200 & $1: 1.5: 0.45$ & 27.40 & 41.09 & 12.33 \\
\hline $0.60 \%$ OPF-1200 & 1200 & $1: 1.5: 0.45$ & 27.40 & 41.09 & 12.33 \\
\hline
\end{tabular}

\section{Curing Process}

After $24 \mathrm{~h}$, all specimens were demoulded and wrapped with a plastic sheet before testing for 7,28 , and 56 days. The curing purpose is to maintain the proper moisture and temperature of the concrete to ensure continuous hydration. Curing was also undertaken to improve the strength of the concrete along with the age of the concrete to achieve the design strength of the FC.

\section{Experimental Arrangement}

The compression test was conducted on a $100 \mathrm{~mm} \times 100 \mathrm{~mm} \times 100 \mathrm{~mm}$ cube according to the BS 12390: Part 3 (BS12390-3, 2011) (see Fig. 3), and the flexural test was performed on a 30 $\mathrm{mm} \times 100 \mathrm{~mm} \times 350 \mathrm{~mm}$ prism according to ASTM C293 (ASTM C293, 2016) (see Fig. 4). The tensile test was conducted on a $100 \mathrm{~mm}$ diameter $\times 200 \mathrm{~mm}$ height cylinder, according to ASTM C496 (ASTM C496, 2017) (see Fig. 5).

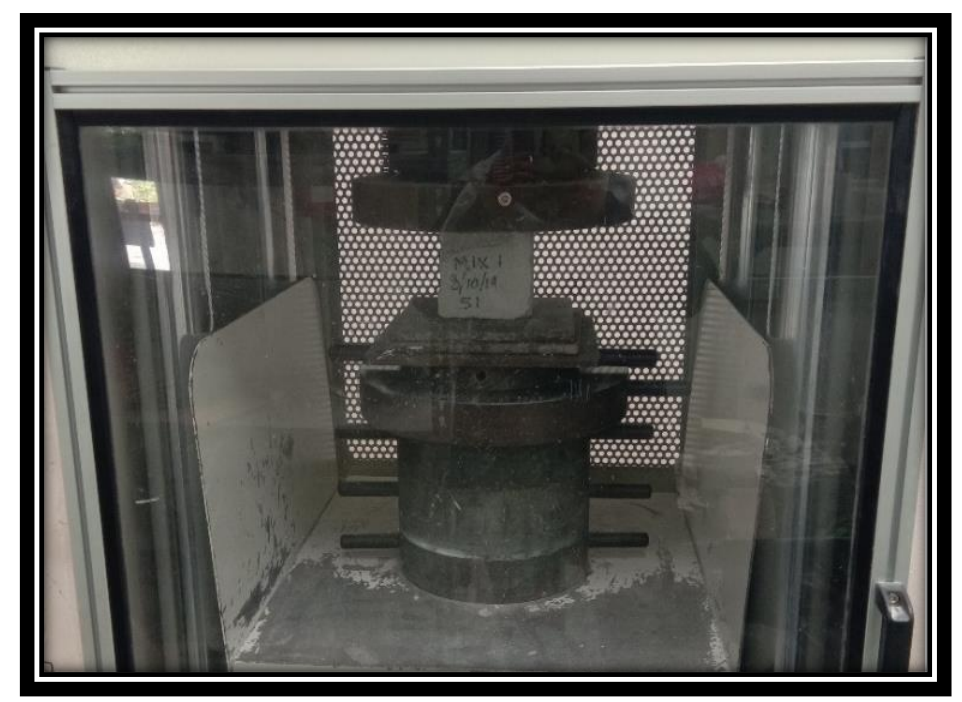

Fig. 3 - Compression Test according to BS EN 12390: Part 3 


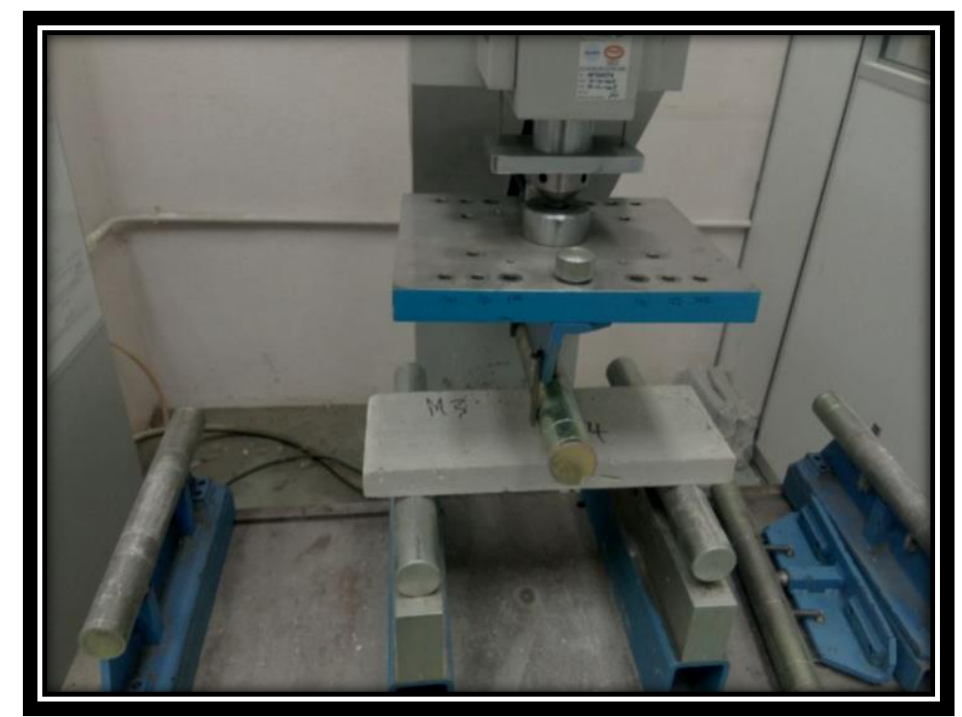

Fig. 4 - The flexural test was performed according to ASTM C293

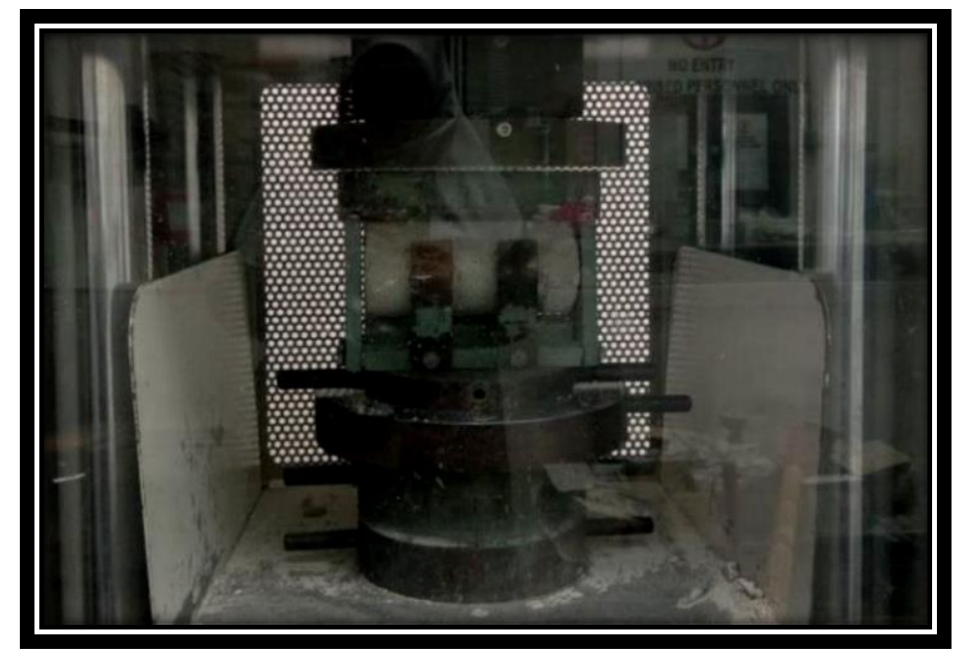

Fig. 5 - The splitting tensile test was carried out according to ASTM C-496

\section{Results and Discussion}

\section{Compressive Strength}

Figures 6 and 7 display the result of the control specimen and LFC's axial compressive strength with the additive of OPT fibre; $600 \mathrm{~kg} / \mathrm{m}^{3}$ and $1200 \mathrm{~kg} / \mathrm{m}^{3}$ densities. As can be seen from these figures, the control specimen (without the inclusion of OPT) has lower compressive strength compared to the LFC with the addition of OPT. The improvement of the compressive strength was observed from day 7 to day 56 . The highest result of compressive strength with $0.45 \%$ OPT for both densities was then compared to other percentages of OPT, which was 1.70 $\mathrm{N} / \mathrm{mm}^{2}$ for $600 \mathrm{~kg} / \mathrm{m}^{3}$ and $6.27 \mathrm{~N} / \mathrm{mm}^{2}$ for $1200 \mathrm{~kg} / \mathrm{m}^{3}$. Accordingly, the OPT fibre helped in preventing the promulgation of cracking in the plastic state in the cement matrix when the load was applied. Furthermore, the lowest result of compressive strength, the control specimen, was $1.24 \mathrm{~N} / \mathrm{mm}^{2}$ for $600 \mathrm{~kg} / \mathrm{m}^{3}$, and $0.60 \%$ of OPT was $5.02 \mathrm{~N} / \mathrm{mm}^{2}$ for $1200 \mathrm{~kg} / \mathrm{m}^{3}$. Aside from that, $0.30 \%$ of OPT was shown for $1.49 \mathrm{~N} / \mathrm{mm}^{2}$ for $600 \mathrm{~kg} / \mathrm{m}^{3}$ and $5.67 \mathrm{~N} / \mathrm{mm}^{2}$ for $1200 \mathrm{~kg} / \mathrm{m}^{3}$. Next, the $0.15 \%$ of OPT showed $1.43 \mathrm{~N} / \mathrm{mm}^{2}$ for $600 \mathrm{~kg} / \mathrm{m}^{3}$ and $5.38 \mathrm{~N} / \mathrm{mm}^{2}$ for $1200 \mathrm{~kg} / \mathrm{m}^{3}$. From Figures 13 and 14, it clearly shows that specimens with $0.45 \%$ of OPT give the optimum compressive strength and the strength dropped when the OPT fibre content is further from $0.45 \%$ to $0.60 \%$. Specimens with $0.45 \%$ of OPT fibre content gave the highest 
compressive strength among all the specimens, and this may be related with the homogeneous dispersion of OPT in FC. Small amount of fibre content can be dispersed well in FC thus increase the packing density of cement composite and this will then increase the compressive strength. The reduction in compressive strength when up to certain fibre content may be triggered by the creation of air void within the mixture with high fibre content (Majid et al., 2012). As fibre content continuous to upsurge, fibre agglomerated and lead to the decrease in compressive strength. According to Sumit et al (2013), increase in OPT fibre content may also lead to reduction of bonding and disintegration. In other words, increase in fibre content may reduce the volume proportion of matrix mix and causes a decreasing in compressive strength (Al Rim et al., 1999). In general, the added fibres to the FC showed better compressive strength over the control specimen since natural fibres have a strong resistance to compression. Based on the data, the use of a higher density of FC increases the compressive strength.

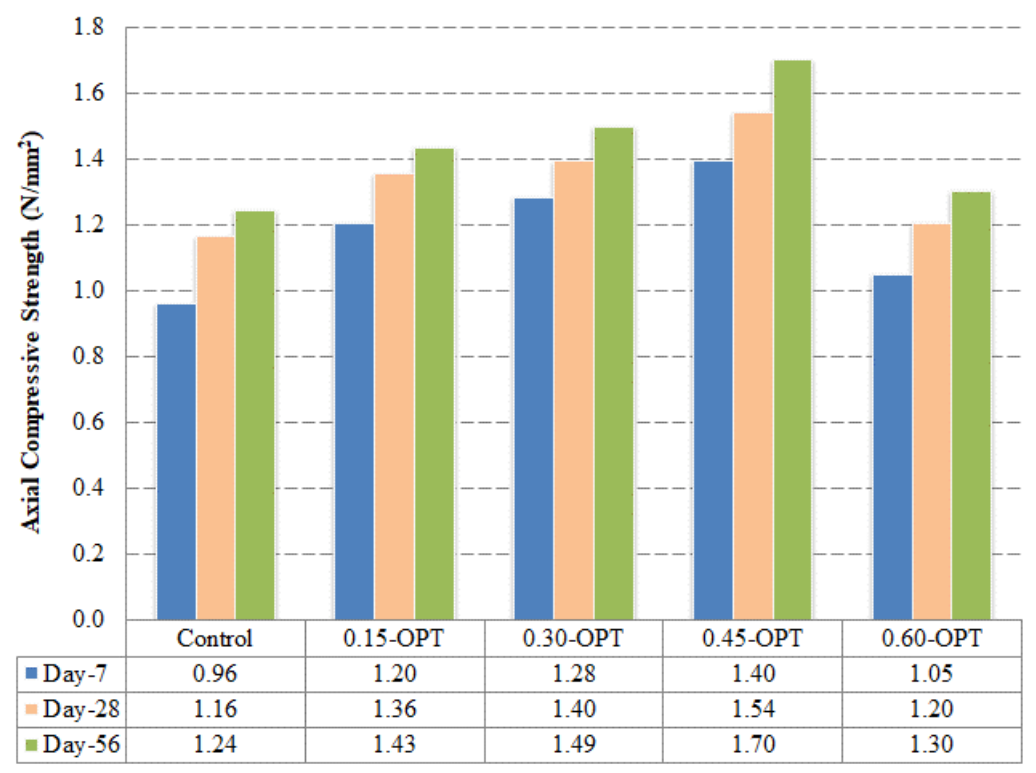

Fig. 6 - Compressive strength result of $600 \mathrm{~kg} / \mathrm{m}^{3}$ density

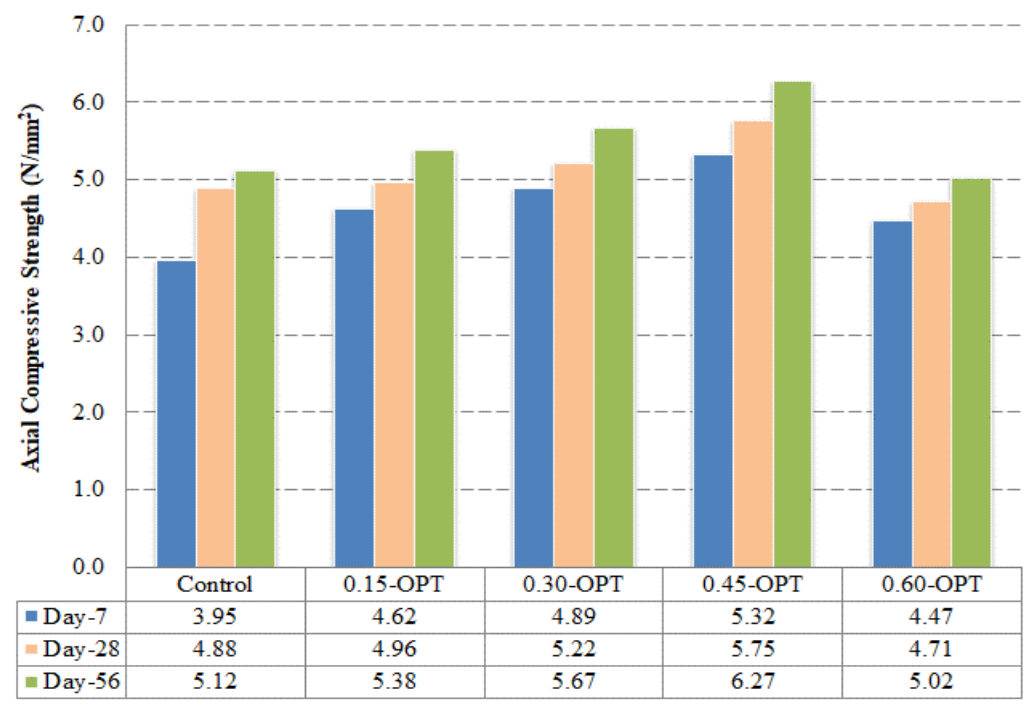

Fig. 7 - Compressive strength result of $1200 \mathrm{~kg} / \mathrm{m}^{3}$ density 


\section{Flexural Strength}

Figures 8 and 9 show the flexural strength for both densities. The graph shows that $0.45 \%$ OPF volume fraction contributed to the highest flexural strength, which is $0.36 \mathrm{~N} / \mathrm{mm}^{2}$ for 600 $\mathrm{kg} / \mathrm{m}^{3}$ density and $1.38 \mathrm{~N} / \mathrm{mm}^{2}$ for $1200 \mathrm{~kg} / \mathrm{m}^{3}$ density. OPT is a reinforcing agent, given its biodegradable attributes. OPT has a high failure strain which can give superior compatibility between the fibres and the matrix. For all the densities used in this research, the increase in flexural strength increased the OPT fibre percentage. For example, $0.15 \%, 0.30 \%$ and $0.60 \%$ of OPT fibre compared to the control sample. However, the flexural strength of FC decreases when exceeding $0.45 \%$. This is because of an incomplete composite. Furthermore, the lowest flexural strength was for the control specimen for $0.16 \mathrm{~N} / \mathrm{mm}^{2}$ for $600 \mathrm{~kg} / \mathrm{m}^{3}$ and $0.73 \mathrm{~N} / \mathrm{mm}^{2}$ for $1200 \mathrm{~kg} / \mathrm{m}^{3}$. Next, as shown in the graph, for the $0.15 \%$ of OPT, it shows a difference of $0.25 \mathrm{~N} / \mathrm{mm}^{2}$ for $600 \mathrm{~kg} / \mathrm{m}^{3}$ and $1.02 \mathrm{~N} / \mathrm{mm}^{2}$ for $1200 \mathrm{~kg} / \mathrm{m}^{3}$. Other than that, $0.30 \%$ of OPT showed $0.27 \mathrm{~N} / \mathrm{mm}^{2}$ for $600 \mathrm{~kg} / \mathrm{m}^{3}$ and $1.08 \mathrm{~N} / \mathrm{mm}^{2}$ for $1200 \mathrm{~kg} / \mathrm{m}^{3}$. Furthermore, $0.60 \%$ of OPT showed $0.22 \mathrm{~N} / \mathrm{mm}^{2}$ for $600 \mathrm{~kg} / \mathrm{m}^{3}$ and $1.17 \mathrm{~N} / \mathrm{mm}^{2}$ for $1200 \mathrm{~kg} / \mathrm{m}^{3}$. Overall, the $\mathrm{FC}$ was shown to be good in terms of compression but brittle under flexural strength. Accordingly, it can be concluded that the flexural strength of lightweight concrete improved with the addiction of OPT fibre as reinforcement for the concrete.

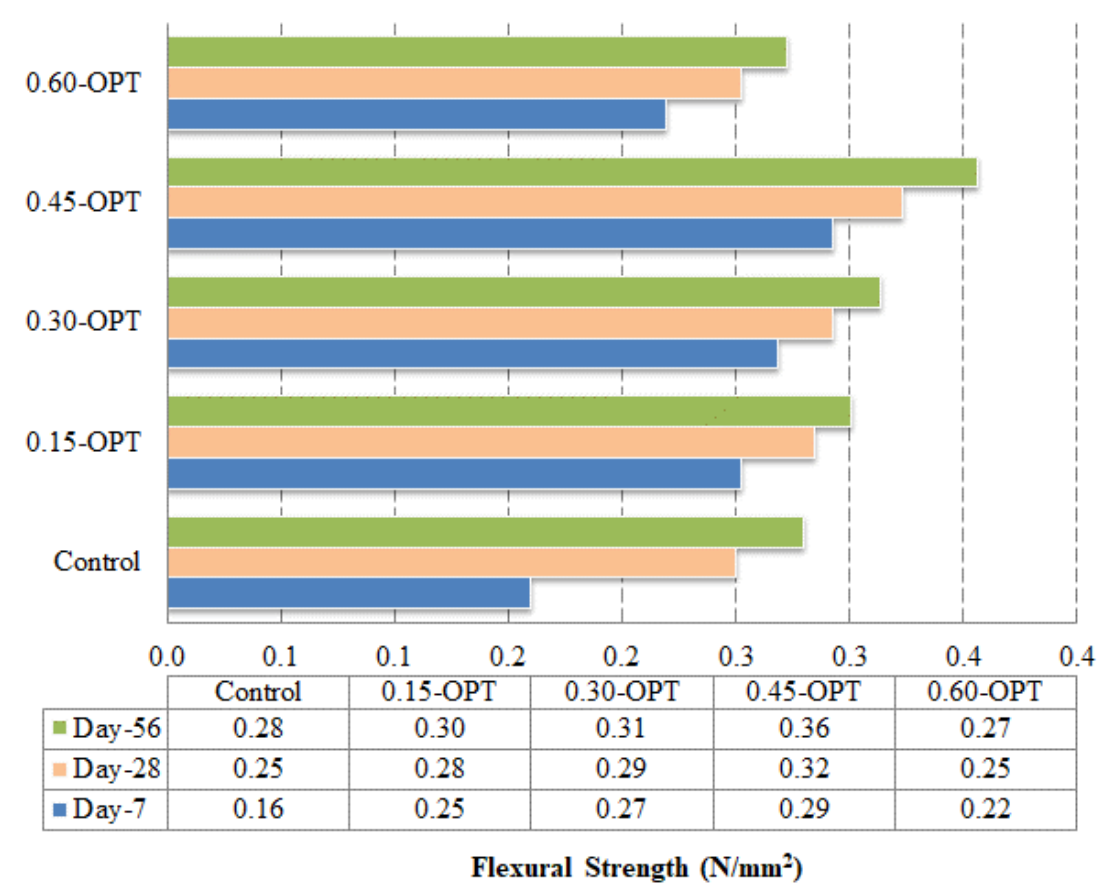

Fig. 8 - Flexural strength result of $600 \mathrm{~kg} / \mathrm{m}^{3}$ density 


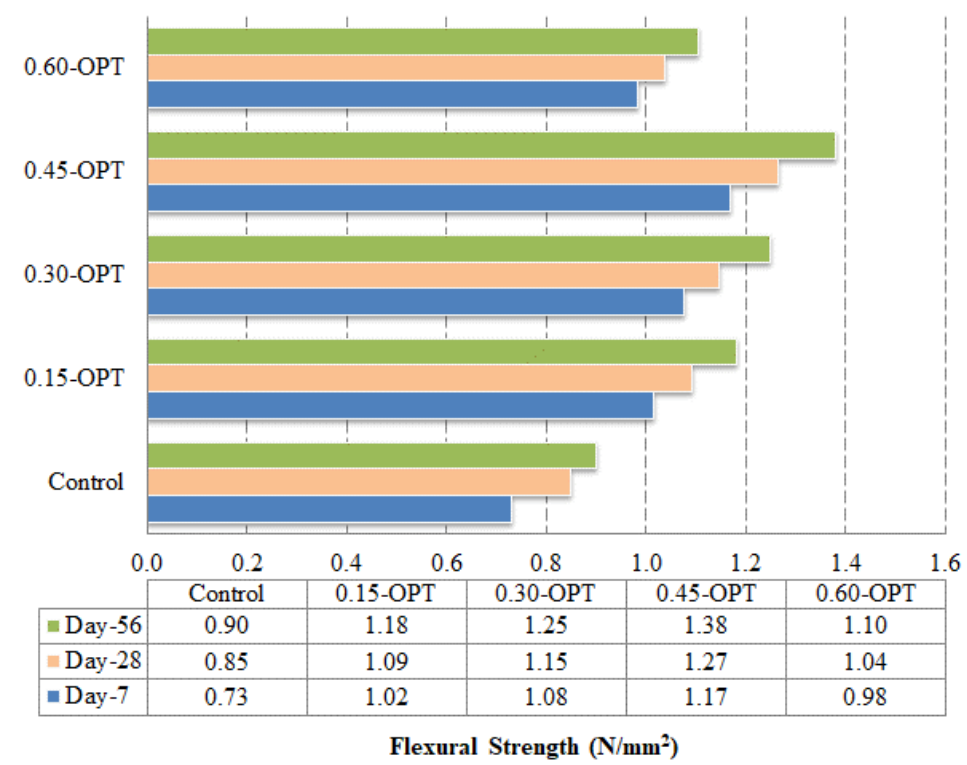

Fig. 9 - Flexural strength result of $1200 \mathrm{~kg} / \mathrm{m}^{3}$ density

\section{Tensile Strength}

Figures 10 and 11 show the result of splitting tensile strength of lightweight FC with the additive of OPT fibre for $600 \mathrm{~kg} / \mathrm{m}^{3}$ and $1200 \mathrm{~kg} / \mathrm{m}^{3}$. FC without OPT has lower compressive strength compared to the lightweight FC with the addition of OPT. The graph shows that $0.45 \%$ OPF volume fraction contributed to the highest splitting tensile strength, which was $0.23 \mathrm{~N} / \mathrm{mm}^{2}$ for $600 \mathrm{~kg} / \mathrm{m}^{3}$ density and $0.88 \mathrm{~N} / \mathrm{mm}^{2}$ for $1200 \mathrm{~kg} / \mathrm{m}^{3}$ density. Furthermore, the lowest result for the compressive strength for the control sample was $0.17 \mathrm{~N} / \mathrm{mm}^{2}$ for 600 $\mathrm{kg} / \mathrm{m}^{3}$ and $0.50 \mathrm{~N} / \mathrm{mm}^{2}$ for $1200 \mathrm{~kg} / \mathrm{m}^{3}$. The tensile strength was also influenced by the density of the mortar. For $0.15 \%$ of OPT it shows $0.20 \mathrm{~N} / \mathrm{mm}^{2}$ for $600 \mathrm{~kg} / \mathrm{m}^{3}$ and $0.76 \mathrm{~N} / \mathrm{mm}^{2}$ for 1200 $\mathrm{kg} / \mathrm{m}^{3}$. Other than that, for $0.30 \%$ of OPT it shows $0.20 \mathrm{~N} / \mathrm{mm}^{2}$ for $600 \mathrm{~kg} / \mathrm{m}^{3}$ and $0.80 \mathrm{~N} / \mathrm{mm}^{2}$ for $1200 \mathrm{~kg} / \mathrm{m}^{3}$. Finally, for $0.60 \%$ of OPT it shows $0.18 \mathrm{~N} / \mathrm{mm}^{2}$ for $600 \mathrm{~kg} / \mathrm{m}^{3}$ density and 0.71 $\mathrm{N} / \mathrm{mm}^{2}$ for $1200 \mathrm{~kg} / \mathrm{m}^{3}$ density.

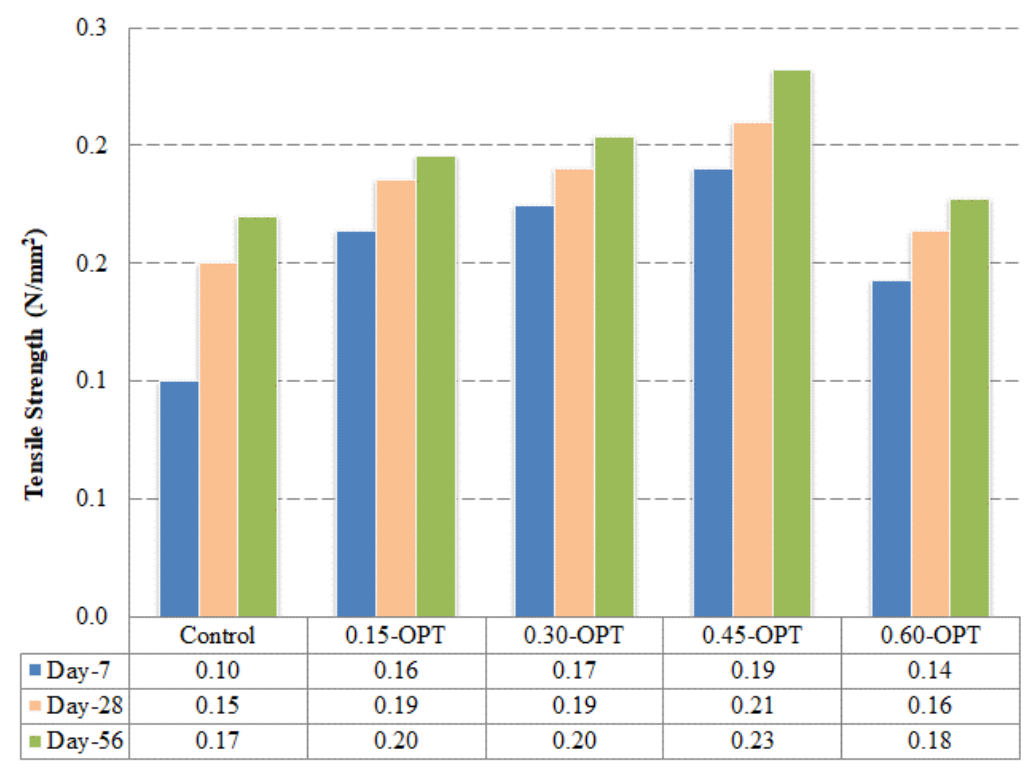

Fig. 10 - Tensile strength result of $600 \mathrm{~kg} / \mathrm{m}^{3}$ density 


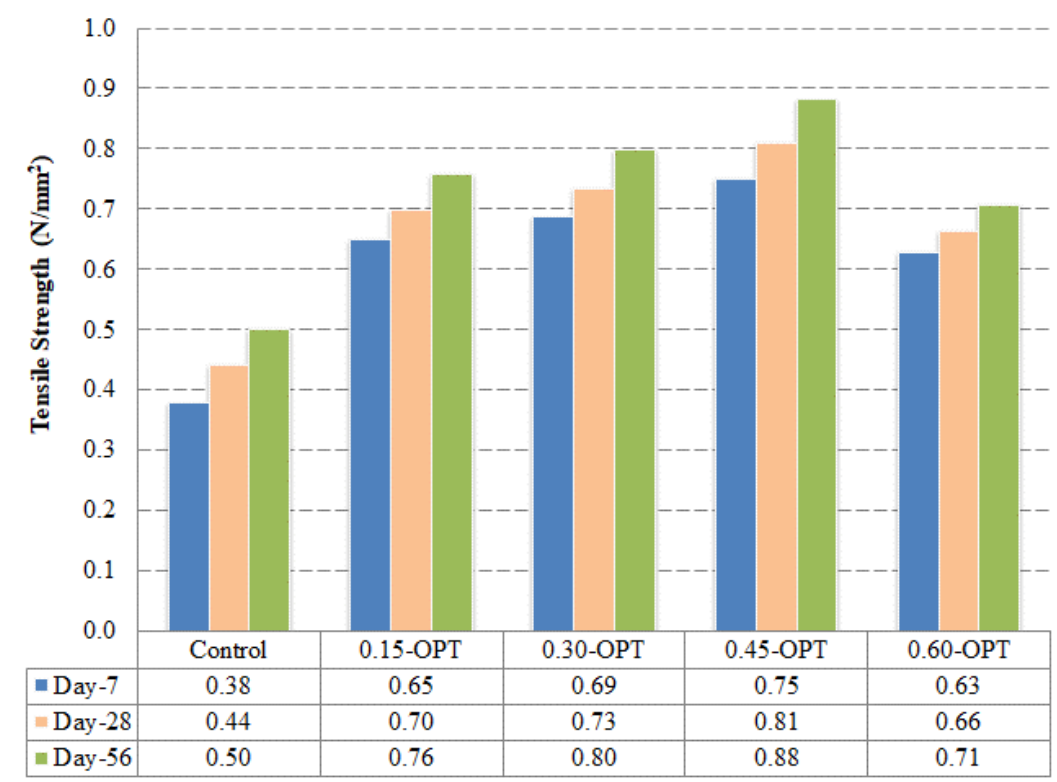

Fig. 11 - Tensile strength result of $1200 \mathrm{~kg} / \mathrm{m}^{3}$ density

\section{Conclusion}

Overall, the strength of the FC in this research improved with the addition of OPT fibre. However, the different percentages of OPT fibre added to the FC gave a different result on the mechanical properties of FC. In general, $0.45 \%$ of OPT fibre volume fraction in FC offered outstanding drying shrinkage, compressive strength and flexural strength compared to other percentages used. It should be highlighted that the outside part of OPT fibre is rough, allowing for the spread of nodes and irregular stripes. Additionally, the OPT cell wall's outside surface was covered with lignin, wax, and oil. Fibre-matrix interface bonding, which is regarded as a coarser surface, is helpful given its surface roughness. Accordingly, it empowers the OPT fibre, and matrix mechanical interlocking, thereby improving both the mechanical properties of the FC. The results of this fundamental study could pave the way to produce high performance FC with the addition of biomass waste from oil palm. Output from this research would give a better insight of the potential utilization of fibre from oil palm in FC.

\section{References}

Al Rim, K., Ledhem, A., Douzane, O., Dheilly, R. M., Queneudec, M. (1999). Influence of The Wood on The Thermal and Mechanical Performances of Clay-Cement-Wood Composites. Cement and Concrete Composites, 21, pp. 269-276.

ASTM C293 / C293M-16. (2016). Standard Test Method for Flexural Strength of Concrete (Using Simple Beam with Center-Point Loading), ASTM International, West Conshohocken, PA

ASTM C496 / C496M-17. (2017). Standard Test Method for Splitting Tensile Strength of Cylindrical Concrete Specimens, ASTM International, West Conshohocken, PA

ASTM C878 / C878M-14a. (2014). Standard Test Method for Restrained Expansion of Shrinkage-Compensating Concrete, ASTM International, West Conshohocken, PA

BS 12. (1996). Specification for Portland cement. British Standards Institution: 1-18

BS 12390-3. (2011). Testing hardened concrete. Compressive strength of test specimens. British Standard Institution: 1-24 
BS 882. (1992). Specification for aggregates from natural sources for concrete. British Standards Institution: 1-14

Elrahman, M. A., El Madawy, M. E., Chung, S. Y., Sikora, P., Stephan, D. (2019). Preparation and characterization of ultra-lightweight foamed concrete incorporating lightweight aggregates. Applied Sciences (Switzerland), 9(7): 1-12

Fu, Y., Wang, X., Wang, L., Li, Y. (2020). Foam Concrete: A State-of-the-Art and State-of-theart Practice Review. Advances in Materials Science and Engineering, 6153602, 1-25

Hamad, A. J. (2014). Materials, production, properties and application of aerated lightweight concrete. International journal of materials science and engineering, 2(2), 152-157.

Jalal, M. D., Tanveer, A., Jagdeesh, K., Ahmed, F. (2017). Foam concrete. International Journal of Civil Engineering Research, 8(1): 1-14 Hedjazi S. (2019). Compressive Strength of Lightweight Concrete. In Intech Open:1-18

Kamaruddin, S., Goh, W. I., Jhatial, A. A., \& Lakhiar, M. T. (2018). Chemical and Fresh State Properties of Foamed Concrete Incorporating Palm Oil Fuel Ash and Eggshell Ash as Cement Replacement. International Journal of Engineering \& Technology, 7(4.30), 350

Kim, Y., Jiong, H., Jae, L., \& Heeyou, B. (2010). "Mechanical Properties of Fiber Reinforced Lightweight Concrete Containing Surfactant", Advances in Civil Engineering, 10, 1-9.

Lim, S. K., Tan, C. S., Lim, O. Y., \& Lee, Y. L. (2013). Fresh and hardened properties of lightweight foamed concrete with palm oil fuel ash as filler.

Mahzabin, M. S., Hock, L. J., Hossain, M. S., Kang, L. S. (2018). The influence of addition of treated kenaf fibre in the production and properties of fibre reinforced foamed composite. Construction and Building Materials, 178: 518-528

Majid, A., Anthony L., Hou, S., Nawawi, C. (2012). Mechanical and dynamic properties of coconut fibre reinforced concrete. Construction and Building Materials, 30, pp. 814-825.

Memon, I. A., Jhatial, A. A., Sohu S., Lakhiar M. T., Hussain Z. (2018). Influence of Fibre Length on the Behaviour of Polypropylene Fibre Reinforced Cement Concrete. Civil Engineering Journal, 4(9): 2124-2131.

Hosseini, M. H., Abdul Awal, A. S. M., \& Sam, A. R. M. (2016). Mechanical and thermal properties of prepacked aggregate concrete incorporating palm oil fuel ash. Sadhana, 41(10), 1235-1244.100

Momeen, M., Islam, U., Mo, K. H., \& Alengaram, U. J. (2016). Durability properties of sustainable concrete containing high volume palm oil waste materials. Journal of Cleaner Production, 137, 167-177.

Moon, A. S., Varghese, V., Waghmare, S. S. (2015). Foam Concrete as A Green Building Material. International Journal for Research in Emerging Science and Technology, 2(9): 25-32.

Müllera, H. S., Breinera, R., Moffatta, J. S., \& Haista, M. (2014). Design and properties of sustainable concrete. Procedia Engineering, 95(Scescm), 290-304

Muthusamy, K., \& Zamri, N. A. (2016). Mechanical Properties of Oil Palm Shell Lightweight Aggregate Concrete Containing Palm Oil Fuel Ash as Partial Cement Replacement. KSCE Journal of Civil Engineering, 20(4), 1473-1481.

Mydin, M. A. O., Musa, M., Ghani, A. N. A. (2016). Fiber glass strip laminates strengthened lightweight foamed concrete: Performance index, failure modes and microscopy analysis. AIP Conference Proceedings, 2018, 020111

Mydin, O. M. A., Noordin, N. M., Utaberta, N., Yunos, M. Y., Segeranazan, S. (2016). Physical properties of foamed concrete incorporating coconut fibre. Jurnal Teknologi, 78(5), 99105 
Ramamurthy, K., Nambiar, K. E. K., \& Indu Siva Ranjani, G. (2009). A classification of studies on properties of foam concrete. Cement and Concrete Composites, 31(6), 388-396.

Sari, K. A. M., Sani, A. R. M. (2017). Applications of Foamed Lightweight Concrete. MATEC Web of Conferences, 97: 1-5.

Serri, E., Mydin, O. M. A., Suleiman, M. Z. (2014). Thermal properties of Oil Palm Shell lightweight concrete with different mix designs. Jurnal Teknologi, 70(1), 155-159

Suhendro, B. (2014). Toward green concrete for better sustainable environment. Procedia Engineering, 95(Scescm), 305-320.

Sumit, C., Sarada, P. K., Aparna, R., Ratan, K. B., Basudam, A., Majumder, S. B. (2013). Improvement of the mechanical properties of jute fiber reinforced cement mortar: $A$ statistical approach. Construction and Building Materials, 38, pp. 776-784.

Tangchirapat, W., \& Jaturapitakkul, C. (2010). Strength, drying shrinkage, and water permeability of concrete incorporating ground palm oil fuel ash. Cement and Concrete Composites, 32(10), 767-774.

Thakrele, M. H. (2014). Experimental study on foam concrete. International journal of Civil Structure Environment Infrastructure Engineering Research and development (IJCSEIERD), 4(1-2014), 145-158. 